\title{
PERILAKU REMAJA DALAM HAL PERUBAHAN FISIOLOGIS PADA MASA PUBERTAS DI SMP YAYASAN PENDIDIKAN SHAFIYYATUL AMALIYYAH MEDAN TAHUN 2013
}

\author{
Dina Indarsita ${ }^{1}$, Mariaty $S^{2}$, Ravina Primursanti ${ }^{1}$ \\ ${ }^{1}$ Jurusan Keperawatan Politeknik Kesehatan Medan \\ ${ }^{2}$ Jurusan Analis Kesehatan Politeknik Kesehatan Medan
}

\begin{abstract}
Abstrak
Latar belakang: Masa pubertas adalah terjadinya perubahan biologis yang meliputi morfologi dan fisiologi yang terjadi dengan pesat dari masa anak kemasa dewasa, terutama kapasitas reproduksi yaitu perubahan alat kelamin dari tahap anak kedewasa. berdasarkan persentase terkecil aspek fisik pada perilaku remaja mengenai keadaan fisik diperoleh 48,4\%. Hal ini mengindikasikan bahwa masih banyak siswa yang memiliki pengetahuan, penilaian serta pengharapan yang belum baik tentang perubahan fisik. Hasil penelitian lain menunjukkan Remaja pada masa pubertas memiliki penerimaan yang positif terhadap perubahan fisik, yaitu sebanyak 78,63\% dan penerimaan negatif terhadap perubahan fisik, yaitu sebanyak $21,37 \%$. Tujuan penelitian : ini adalah untuk mengetahui perilaku remaja dalam hal perubahan fisiologis pada masa pubertas di SMP Yayasan Pendidikan Shafiyyatul Amaliyyah Medan Tahun 2013. Metodologi : Desain penelitian yang digunakan dalam penelitian ini adalah deskriptif dengan pendekatan cross sectional. Jumlah sampel dalam penelitian ini adalah 173 orang dengan tehnik pengambilan sampel adalah secara proporsi bertingkat (proportional stratified sampling) dan acak sederhana (simple random sampling). Penelitian ini dilakukan pada bulan April 2013. Hasil : Hasil penelitian diperoleh pengetahuan remaja berpengetahuan baik sebanyak 134 orang $(77,5 \%)$, berpengetahuan cukup sebanyak 36 orang $(20,8 \%)$, dan berpengetahuan kurang sebanyak 3 orang (1,7 \%), sikap remaja mayoritas memiliki sikap positif sebanyak 162 orang $(93,6 \%)$ dan minoritas memiliki sikap negatif sebanyak 11 orang $(6,4 \%)$, tindakan remaja diperoleh tindakan baik sebanyak 157 orang ( $90,8 \%$ ) dan tindakan kurang sebanyak 16 orang (9,2\%). Dari hasil penelitian ini diketahui bahwa perilaku remaja awal dalam hal perubahan fisiologis di SMP Yayasan Pendidikan Shafiyyatul Amaliyyah Medan Tahun 2013 baik.
\end{abstract}

Kata kunci : perilaku, remaja, fisiologis

\section{PENDAHULUAN}

\section{Latar Belakang}

Masa pubertas adalah terjadinya perubahan biologis yang meliputi morfologi dan fisiologi yang terjadi dengan pesat dari masa anak kemasa dewasa, terutama kapasitas reproduksi yaitu perubahan alat kelamin dari tahap anak kedewasa. (Soetjiningsih, 2004).

Dalam usahanya mencari identitas dirinya sendiri, seorang remaja sering membantah orang tuanya karena ia mulai punya pendapat-pendapat sendiri, cita-cita serta nilai-nilai sendiri yang berbeda dengan orangtuanya. Perubahan-perubahan sekunder juga terjadi, badan bertambah tinggi dengan cepat. Hal ini disebabkan masa remaja merupakan masa transisi antara masa kanak-kanak dan masa dewasa. Masa transisi ini seringkali menghadapkan individu yang bersangkutan kepada situasi yang membingungkan, disatu pihak ia masih kanak-kanak, tetapi dilain pihak ia harus bertingkah laku seperti orang dewasa.

Di Asia Pasifik dimana penduduknya merupakan $60 \%$ dari penduduk dunia, seperlimanya adalah remaja umur 10-19 tahun. Di Indonesia menurut Biro Pusat
Statistik (1999) kelompok umur 10-19 tahun adalah sekitar 225 , yang terdiri dari $50,9 \%$ remaja laki-laki dan $49,1 \%$ remaja perempuan (dikutip dari Nancy P,2002).

Para ahli merumuskan bahwa pubertas digunakan untuk menyatakan perubahan biologis baik bentuk maupun fisiologis yang terjadi dengan cepat dari masa anak-anak ke masa dewasa, terutama perubahan alat reproduksi, sedangkan istilah adolescence lebih ditekankan pada perubahan psikososial atau kematangan yang menyertai masa pubertas (Poltekkes Depkes Jakarta, 2010)

Dalam rentang waktu ini terjadi pertumbuhan fisik yang cepat, termasuk pertumbuhan serta kematangan dari fungsi organ reproduksi. Seiring dengan pertumbuhan fisik, remaja juga mengalami perubahan kejiwaan. Remaja menjadi individu yang sensitive, mudah menangis, mudah cemas, frustasi, tetapi juga mudah

tertawa. Perubahan emosi menjadikan remaja sebagai individu yang agresif dan mudah bereaksi terhadap rangsangan. Remaja mulai mampu berfikir abstrak, senang mengkritik, dan ingin mengetahui hal yang baru.

Salah satu Perguruan Tinggi Negeri Surabaya melakukan penelitian di Jawa Timur terkait dengan usia pubertas yang hasilnya masa pubertas pada perempuan 
dimulai usia 12,5 tahun dengan puncak pubertas pada usia 15 tahun. Sedangkan masa pubertas laki-laki lebih lambat, yaitu dimulai pada usia 13 tahun dengan puncak pubertas 16 tahun (Rahmawati, 2010).

Perubahan fisik pubertas dimulai sekitar usia 10 atau 11 tahun pada remaja putri, kira-kira 2 tahun sebelum perubahan pubertas pada remaja laki-laki. Kematangan seksual dan terjadinya perubahan bentuk tubuh sangat berpengaruh pada kehidupan kejiwaan remaja, sementara itu perhatian remaja sangat besar terhadap penampilan dirinya sehingga mereka sering merisaukan bentuk tubuhnya yang kurang proporsional tersebut. Apabila mereka sudah dipersiapkan dan mendapatkan informasi tentang perubahan tersebut maka mereka tidak akan mengalami kecemasan dan reaksi negatif lainnya, tetapi bila mereka kurang memperoleh informasi, maka akan merasakan pengalaman yang negatif (Soetjiningsih, 2004).

Tumbuh kembang merupakan proses yang berkesinambungan yang terjadi sejak intrauterin dan terus berlangsung sampai dewasa. Dalam proses mencapai dewasa inilah anak harus melalui berbagai tahap tumbuh kembang, termasuk tahap remaja. Tahap remaja adalah masa transisi antara masa anak dan dewasa, dimana terjadi pacu tumbuh (growth spurt), timbul ciri seks sekunder, tercapai fertilitas dan terjadi perubahan-perubahan psikologik serta kognitif. Untuk tercapainya tumbuh kembang yang optimal tergantung pada potensi biologiknya (Santrock, JW. 2003).

Pada masa ini seorang anak tidak lagi hanya bersifat reaktif, tetapi juga anak mulai aktif mencapai kegiatan dalam rangka menemukan dirinya, serta mencari pedoman hidup, untuk bekal kehidupan mendatang. Pada kegiatan anak dalam rangka penemuan akunya itu anak mulai menyadari akan keberadaan dirinya, yang lebih dalam dibanding pada sebelumnya. Oleh karena itu anak menjadi agak bersikap tertutup (introvert), dan lebih senang mengungkap pengalamannya itu pada buku harian, senang termenung, dan lain-lain.

Solihah (2007 : 144) menyatakan bahwa permasalahan yang paling banyak dikonsultasikan remaja pada MCR (Mitra Citra Remaja) Jawa Barat saat masa pubertas, yaitu permasalahan yang berkaitan dengan perubahan fisik $27 \%$, kekhawatiran pada masa puber $16 \%$, pubertas sebagai awal masa remaja $10,1 \%$, dan keadaan emosi 7,6\%.

Yulianto (2012) menjelaskan, berdasarkan persentase terkecil aspek fisik pada perilaku remaja mengenai keadaan fisik diperoleh 48,4\%. Hal ini mengindikasikan bahwa masih banyak siswa yang memiliki pengetahuan, penilaian serta pengharapan yang belum baik tentang perubahan fisik.

Berdasarkan penelitian Yulianto, H (2012) dengan menggunakan Daftar Cek Masalah (DCM) yang telah dilakukan di SMA Negeri 24 Bandung Tahun Ajaran 2010-2011, menunjukkan adanya konsep diri negatif pada siswa. Hal ini dapat dilihat pada perilaku siswa X Tahun Ajaran 2010-2011 yang merasa tidak percaya diri dengan fisik yang dimiliki, timbullah ejekan antar teman mengenai bentuk fisik yang menyebabkan siswa menjadi tidak percaya diri dalam bergaul, serta adanya perilaku yang tidak sesuai dengan etika dan nilai-nilai yang berlaku di sekolah ataupun di masyarakat. Dilihat dari fenomenafenomena yang dipaparkan diatas, banyak siswa yang mengkhawatirkan, memiliki penilaian yang rendah terhadap diri sendiri, berperilaku salah serta tidak merasa puas terhadap perubahan fisik yang terjadi.

Berdasarkan penelitian Dewi, P. (2010) mengenai perilaku remaja dalam menghadapi pubertas. Penelitian ini melibatkan siswa SMPN 1 Sungai Sarik Kecamatan VII Koto Kabupaten Padang Pariaman dengan jumlah sampel 124 responden. Desain yang digunakan pada penelitian ini adalah crosssectional. Instrument yang digunakan adalah kuesioner. Terdapat hubungan yang bermakna antara kecemasan dan perubahan perilaku remaja dalam menghadapi perubahan fisik pubertas (p 0,003).

Berdasarkan penelitian Fatwiany (2010) mengenai perubahan fisik remaja pada masa pubertas. Penelitian ini melibatkan siswa SLTP Kemala Bhayangkari 1 Medan dengan jumlah sampel 117 orang. Penelitian ini bersifat deskriptif korelasi. Hasil penelitian menunjukkan Remaja putri pada masa pubertas memiliki penerimaan yang positif terhadap perubahan fisik, yaitu sebanyak 78,63\%, dan penerimaan negatif terhadap perubahan fisik, yaitu sebanyak $21,37 \%$. Berdasarkan hasil penelitian didapatkan nilai $\mathrm{p}=0,002$, ini menunjukkan adanya hubungan yang signifikan antara konsep diri terhadap penerimaan perubahan fisik remaja putri pada masa pubertas.

Berdasarkan literatur diatas, maka peneliti tertarik meneliti tentang perilaku remaja awal dalam hal perubahan fisiologis pada masa pubertas.

\section{RUMUSAN MASALAH}

Dari latar belakang di atas maka rumusan masalah dalam penelitian ini adalah Bagaimana perilaku remaja dalam hal perubahan fisiologis pada masa pubertas di SMP Yayasan Pendidikan Shafiyyatul Amaliyyah Medan Tahun 2013.

\section{TUJUAN PENELITIAN}

1. Untuk mengetahui perilaku remaja dalam hal perubahan fisiologis pada masa pubertas di SMP Yayasan Pendidikan Shafiyyatul Amaliyyah Medan Tahun 2013.

2. Untuk mengetahui pengetahuan remaja dalam menghadapi perubahan fisiologis pada masa pubertas di SMP Yayasan Pendidikan Shafiyyatul Amaliyyah Medan Tahun 2013.

3. Untuk mengetahui sikap remaja dalam menghadapi perubahan fisiologis pada masa pubertas di SMP Yayasan Pendidikan Shafiyyatul Amaliyyah Medan Tahun 2013.

4. Untuk mengetahui tindakan remaja dalam menghadapi perubahan fisiologis pada masa pubertas di SMP Yayasan Pendidikan Shafiyyatul Amaliyyah Medan Tahun 2013. 


\section{MANFAAT PENELITIAN}

1. Sebagai sumber informasi dan bahan masukan bagi remaja yang terdiri dari pengetahuan, sikap, dan tindakan dalam menghadapi perubahan fisiologis

2. Sebagai bahan masukan bagi instansi dalam memberikan informasi yang jelas kepada remaja di SMP Yayasan Pendidikan Shafiyyatul Amaliyyah Medan untuk berperilaku yang sesuai dalam menghadapi perubahan fisiologis pada masa pubertas.

\section{METODOLOGI PENELITIAN}

\section{Desain Penelitian}

Desain penelitian yang digunakan dalam penelitian ini adalah bersifat deskriptif, dengan pendekatan cross sectional yang bertujuan untuk mengetahui perilaku remaja terhadap perubahan fisiologis pada masa pubertas di SMP Yayasan Pendidikan Shafiyyatul Amaliyyah Medan Tahun 2013.

\section{Populasi}

Populasi adalah keseluruhan objek penelitian atau objek yang diteliti. Populasi dalam penelitian ini adalah seluruh remaja yang berusia 12 sampai 15 tahun di SMP Yayasan Pendidikan Shafiyyatul Amaliyyah Medan tahun ajaran 2012/2013, dengan jumlah siswa sebanyak 304 siswa.

\section{Sampel}

Sampel adalah sebagian dari keseluruhan objek penelitian yang diteliti dan dianggap mewakili seluruh populasi.

\section{a) Besaran sampel}

Besaran sampel ditentukan dengan menggunakan rumus :

$$
\mathrm{n}=\frac{N}{1+N(d)^{2}}
$$

Keterangan :

$\mathrm{N}=$ Besar Populasi

$\mathrm{n}=$ Besar Sampel

$\mathrm{d}=$ Tingkat kepercayaan/ketepatan yang diinginkan $(0,1)$

Didapat jumlah sampel :

$$
\begin{aligned}
\mathrm{n} & =\frac{304}{1+304(0,1)^{2}} \\
& =\frac{304}{1,76}=172,73 \text { (dibulatkan menjadi }
\end{aligned}
$$$$
173 \text { siswa) }
$$

Jadi, sampel dalam penelitian ini adalah sebanyak 173 responden.

\section{b) Tekhnik pengambilan sampel}

Sampel dalam penelitian ini diambil secara proporsi bertingkat (proportional stratified sampling) dan acak sederhana (simple random sampling).

\section{LOKASI PENELITIAN}

Penelitian ini dilakukan di SMP Yayasan Pendidikan Shafiyyatul Amaliyyah Medan dengan pertimbangan bahwa di Sekolah ini belum pernah dilakukan penelitian mengenai perilaku remaja dalam hal perubahan fisiologis pada masa pubertas dan populasi remaja cukup untuk memenuhi target populasi.

\section{HASIL PENELITIAN}

1. Distribusi Pengetahuan remaja dalam hal perubahan fisiologis di SMP Yayasan Pendidikan Shafiyyatul Amaliyyah Medan Tahun 2013.

a. Distribusi Responden Berdasarkan Pertanyaan Pengetahuan Remaja dalam hal perubahan fisiologis adalah sebagai berikut :

Berdasarkan hasil penelitian, distribusi jawaban responden tentang pengetahuan, mayoritas menjawab Benar adalah pernyataan No. 1 tentang pengertian perubahan yang normal (fisiologis) pada remaja yaitu 171 orang $(98,8 \%)$, sedangkan mayoritas responden yang menjawab Salah adalah pernyataan No. 8 tentang salah satu ciri tahap pubertas yaitu 49 orang $(28,3 \%)$. Secara rinci dapat dilihat pada tabel 1 .

Tabel 1. Distribusi Responden Berdasarkan Pertanyaan Pengetahuan Remaja dalam hal perubahan

\begin{tabular}{|c|c|c|c|c|c|}
\hline \multirow{3}{*}{ No } & \multirow{3}{*}{ Pernyataan } & \multicolumn{4}{|c|}{ Pilihan Jawaban } \\
\hline & & \multicolumn{2}{|c|}{ Benar } & \multicolumn{2}{|c|}{ Salah } \\
\hline & & $\mathrm{f}$ & $\%$ & $\mathrm{~F}$ & $\%$ \\
\hline 1 & $\begin{array}{l}\text { Pengertian perubahan yang } \\
\text { normal (fisiologis) pada remaja. }\end{array}$ & 171 & 98,8 & 2 & 1,2 \\
\hline 2 & $\begin{array}{l}\text { Yang termasuk perubahan fisik } \\
\text { yang normal pada remaja }\end{array}$ & 152 & 87,9 & 21 & 12,1 \\
\hline 3 & $\begin{array}{l}\text { Bagian manakah dari tubuh } \\
\text { remaja yang terlebih dahulu } \\
\text { mengalami perubahan }\end{array}$ & 155 & 89,6 & 18 & 10,4 \\
\hline 4 & Perubahan proporsi tubuh & 157 & 90,8 & 16 & 9,2 \\
\hline 5 & Ciri-ciri seks primer & 127 & 73,4 & 46 & 26,6 \\
\hline 6 & Ciri-ciri seks sekunder & 131 & 75,7 & 42 & 24,3 \\
\hline 7 & Salah satu ciri seks sekunder & 146 & 84,4 & 27 & 15,6 \\
\hline 8 & $\begin{array}{l}\text { Yang merupakan salah satu ciri- } \\
\text { ciri tahap pubertas }\end{array}$ & 124 & 71,7 & 49 & 28,3 \\
\hline 9 & $\begin{array}{l}\text { Yang merupakan salah satu ciri- } \\
\text { ciri seks sekunder }\end{array}$ & 148 & 85,5 & 25 & 14,5 \\
\hline 10 & $\begin{array}{l}\text { Perubahan kematangan fisik } \\
\text { yang meliputi perubahan tubuh } \\
\text { dan hormonal termasuk } \\
\text { pengertian }\end{array}$ & 148 & 85,5 & 25 & 14,5 \\
\hline
\end{tabular}
fisiologis di SMP Yayasan Pendidikan Shafiyyatul Amaliyyah Medan Tahun 2013 
b. Distribusi Pengetahuan Remaja dalam hal perubahan fisiologis adalah sebagai berikut :

Dari hasil penelitian diperoleh bahwa pengetahuan remaja berpengetahuan baik sebanyak 134 orang $(77,5 \%)$, berpengetahuan cukup sebanyak 36 orang $(20,8 \%)$, dan berpengetahuan kurang sebanyak 3 orang $(1,7 \%)$. Hal ini dapat dilihat pada tabel 2 .

Tabel 2. Distribusi Pengetahuan Remaja dalam hal perubahan fisiologis di SMP Yayasan Pendidikan Shafiyyatul Amaliyyah Medan Tahun 2013

\begin{tabular}{ccc}
\hline Pengetahuan & Frekuensi (f) & Persentasi (\%) \\
\hline Baik & 134 & 77,5 \\
Cukup & 36 & 20,8 \\
Kurang & 3 & 1,7 \\
\hline Total & 173 & 100 \\
\hline
\end{tabular}

2. Distribusi sikap remaja dalam hal perubahan fisiologis di SMP Yayasan Pendidikan Shafiyyatul Amaliyyah Medan Tahun 2013

a. Distribusi Sikap Remaja dalam hal perubahan fisiologis adalah sebagai berikut:

Distribusi frekuensi berdasarkan sikap remaja dari 173 responden mayoritas memiliki sikap positif sebanyak 162 orang $(93,6 \%)$ dan minoritas memiliki sikap negatif sebanyak 11 orang $(6,4 \%)$. Hal ini dapat dilihat pada tabel 3.

Tabel 3. Distribusi Sikap Remaja dalam hal perubahan fisiologis di SMP Yayasan Pendidikan Shafiyyatul Amaliyyah Medan Tahun 2013

\begin{tabular}{ccc}
\hline Sikap & Frekuensi (f) & Persentasi (\%) \\
\hline Negatif & 11 & 6,4 \\
Positif & 162 & 93,6 \\
\hline Total & 173 & 100 \\
\hline
\end{tabular}

3. Distribusi tindakan remaja dalam hal perubahan fisiologis di SMP Yayasan Pendidikan Shafiyyatul Amaliyyah Medan Tahun 2013.

a. Distribusi Tindakan Remaja dalam hal perubahan fisiologis adalah sebagai berikut :

Distribusi frekuensi berdasarkan tindakan remaja remaja diperoleh tindakan baik sebanyak 157 orang $(90,8 \%)$ dan tindakan kurang sebanyak 16 orang $(9,2 \%)$. Hal ini dapat dilihat pada tabel 4 .

Tabel 4. Distribusi Tindakan Remaja dalam hal perubahan fisiologis di SMP Yayasan Pendidikan Shafiyyatul Amaliyyah Medan Tahun 2013

\begin{tabular}{ccc}
\hline Tindakan & Frekuensi (f) & Persentasi (\%) \\
\hline Baik & 157 & 90,8 \\
Kurang & 16 & 9,2 \\
\hline Total & 173 & 100 \\
\hline
\end{tabular}

4. Distribusi perilaku remaja dalam hal perubahan fisiologis di SMP Yayasan Pendidikan Shafiyyatul Amaliyyah Medan Tahun 2013.

Distribusi frekuensi berdasarkan perilaku remaja remaja diperoleh perilaku baik sebanyak 88 orang $(50,9 \%)$ dan perilaku kurang sebanyak 85 orang (49,1\%). Hal ini dapat dilihat pada table 5 .

Tabel 5. Distribusi Perilaku Remaja dalam hal perubahan fisiologis di SMP Yayasan Pendidikan Shafiyyatul Amaliyyah Medan Tahun 2013

\begin{tabular}{ccc}
\hline Perilaku & Frekuensi (f) & Persentasi (\%) \\
\hline Baik & 88 & 50,9 \\
Kurang & 85 & 49,1 \\
\hline Total & 173 & 100 \\
\hline
\end{tabular}

\section{PEMBAHASAN}

1. Pengetahuan Remaja dalam hal perubahan fisiologis pada masa pubertas di SMP Yayasan Pendidikan Shafiyyatul Amaliyyah Medan Tahun 2013

Pada tabel 2. dapat diamati bahwa pengetahuan remaja sebagian besar berpengetahuan baik sebanyak 136 orang $(78,6 \%)$, dan sebagian kecil berpengetahuan kurang sebanyak 3 orang $(1,7 \%)$.

Hal ini menyatakan bahwa responden yang memiliki tingkat pengetahuan tinggi karena responden telah memasuki sekolah pada tingkat menengah pertama dan telah terpapar dengan pengetahuan tentang perubahan fisiologis dari pendidikan di sekolah.

Pernyataan ini juga didukung oleh penelitian Dewi, P (2010) diperoleh pengetahuan remaja sebagian besar baik yaitu sebanyak 20 orang (55,6 \%), berpengetahuan cukup sebanyak 9 orang $(25 \%)$ dan berpengetahuan kurang sebanyak 7 orang $(19,4 \%)$

Menurut Notoatmodjo (2007) pengetahuan merupakan hasil tahu dan ini terjadi setelah orang melakukan penginderaan terhadap objek tertentu. Sebagian besar pengetahuan manusia diperoleh melalui pendidikan, pengalaman diri sendiri, media dan lingkungan. Pengetahuan baik dan cukup dapat dipengaruhi oleh beberapa faktor seperti: sumber informasi, faktor pendidikan. Semakin banyak seseorang mendapatkan informasi akan mempengaruhi tingkat pengetahuan seseorang.

Dengan mempunyai pengetahuan yang cukup tentang kesehatan reproduksi diharapkan remaja dapat mengambil keputusan yang lebih bijak tentang apa yang seharusnya boleh mereka lakukan dan apa yang seharusnya belum boleh mereka lakukan

2. Sikap Remaja dalam hal perubahan fisiologis pada masa pubertas di SMP Yayasan Pendidikan Shafiyyatul Amaliyyah Medan Tahun 2013

Pada tabel 3. dapat diamati bahwa sikap remaja sebagian besar bersikap positif sebanyak 162 
orang $(93,6 \%)$ dan sebagian kecil yang bersikap negatif sebanyak 11 orang $(6,4 \%)$.

Hal ini menunjukkan bahwa remaja yang memiliki sikap positif telah meyakini bahwa telah siap menghadapi perubahan fisiologis secara baik. Sikap positif dan negatif dapat dipengaruhi oleh pengalaman langsung yang dialami individu terhadap sesuatu hal dan sikap tidak dibawa sejak lahir tetapi dipelajari dan dibentuk berdasarkan pengalaman individu sepanjang perkembangan selama hidupnya, sikap ini tidak lepas dari pengaruh interaksi manusia satu dengan yang lain. Sedangkan remaja yang memiliki sikap negatif disebabkan belum siap menghadapi perubahan fisiologis yang dialaminya dan juga kurang mendapat informasi mengenai perubahan fisiologis. Remaja yang kurang akan pengetahuan tersebut menjadi rendah diri pada saat suaranya mulai membesar, ditambah perubahan fisik dan wajahnya yang berjerawat, sehingga perubahan tersebut membuat remaja menarik diri. Menghadapi perubahan yang cukup pesat ini remaja seringkali tidak pernah cukup untuk mengenal tubuh.

Pernyataan ini juga didukung dengan hasil penelitian Fatwiany (2010), diperoleh responden yang bersikap positif terhadap perubahan fisiologis sebanyak $78,63 \%$ dan yang bersikap negatif terhadap perubahan fisiologis sebanyak 21,37\%.

Menurut Sunaryo (2004) sikap adalah kecenderungan bertindak dari individu, berupa respons tertutup terhadap stimulus ataupun objek tertentu. Secara nyata sikap menunjukkan adanya keyakinan seseorang mengenai objek atau situasi yang disertai adanya perasaan tertentu dan memberikan dasar pada orang tersebut untuk membuat respons atau berperilaku dalam cara tertentu yang dipilihnya.

Sikap yang positif akan menjadi salah satu tolok ukur kematangan seseorang, ditandai dengan konsep diri yang memiliki kemampuan untuk melihat gambaran diri yang pada akhirnya akan membentuk rasa percaya diri.

\section{Tindakan Remaja dalam hal perubahan fisiologis pada masa pubertas di SMP Yayasan Pendidikan Shafiyyatul Amaliyyah Medan Tahun 2013 \\ Pada tabel 4. diperoleh sebagian besar remaja} memiliki tindakan baik yaitu sebanyak 157 orang $(90,8$ $\%)$ dan tindakan kurang sebanyak 16 orang $(9,2 \%)$. Hal ini menunjukkan bahwa remaja - remaja yang memiliki tindakan baik melakukan tindakan sesuai dengan perubahan fisiologis yang dialaminya dan remaja yang memiliki tindakan kurang tidak melakukan hal - hal yang sesuai dengan perubahan fisiologis yang dialaminya.

Pernyataan ini juga sesuai dengan penelitian Dewi, P (2010) yaitu sebagian besar remaja memiliki tindakan positif sebanyak 24 orang $(72,7 \%)$ dan yang memiliki tindakan negatif sebanyak negatif sebanyak 9 orang $(27,3 \%)$.

Menurut Notoatmodjo (2007), tindakan atau praktek dilaksanakan setelah seseorang mengetahui stimulus atau objek kemudian mengadakan penilaian terhadap apa yang diketahui. Dengan kata lain tindakan atau praktek dilaksanakan karena dinilai baik dan diyakini.

Kecerdasan pengetahuan, individu lebih mudah mengendalikan perilaku dan dorongan - dorongan dari dalam individu tersebut dalam melakukan suatu tindakan. Remaja dapat memahami bahwa tindakan yang dilakukan pada saat ini dapat memiliki efek pada masa yang akan datang. Dengan demikian, remaja mampu memperkirakan konsekuensi dari tindakannya. Perkembangan kognitif yang dimiliki remaja dapat dikembangkan dan di aplikasikan dalam kehidupannya sehingga mereka mempunyai pola berfikir dan mampu menentukan tindakan dari apa yang telah mereka ketahui.

\section{Perilaku Remaja dalam hal perubahan fisiologis pada masa pubertas di SMP Yayasan Pendidikan Shafiyyatul Amaliyyah Medan Tahun 2013 \\ Pada hasil penelitian diketahui bahwa} sebagian besar remaja memiliki perilaku baik yaitu sebanyak 88 orang $(50,9 \%)$ dan sebagian kecil memiliki perilaku kurang yaitu sebanyak 85 orang ( $49,1 \%$ ). Hal ini menunjukkan bahwa remaja yang memiliki perilaku baik telah melakukan sesuai dengan perubahan fisiologis yang dialami berdasarkan pengetahuan yang dimiliki sedangkan remaja yang masih kurang memperhatikan perubahan fisiologis yang dialaminya masih mempunyai perilaku kurang.

Pernyataan ini juga sesuai dengan penelitian Dewi, P (2010) yaitu sebagian besar remaja memiliki perilaku baik sebanyak 28 orang $(77,7 \%)$ dan sebagian kecil memiliki perilaku kurang yaitu sebanyak 8 orang $22,3(\%)$.

Sesuai dengan pendapat (Notoatmodjo, 2007) dimana perilaku merupakan respons seseorang atau tindakan seseorang terhadap stimulus (rangsangan dari luar) yang merupakan kumpulan berbagai faktor saling berinteraksi. Sehingga dapat dilaksanakan jika tindakan tersebut di nilai baik dan diyakini.

Faktor - faktor yang dapat mempengaruhi perilaku individu dapat memberikan pengaruh yang baik sehingga individu memiliki perilaku yang baik. Dalam hal ini sekolah hendaknya memberikan bantuan agar setiap individu dapat memiliki perilaku yang baik dan terhindar dari timbulnya gejala ketidak sesuaian, sehingga sekolah hendaknya berfungsi sebagai suatu lingkungan yang memberikan kemudahan dan mendukung terciptanya perilaku yang baik. Remaja yang sedang memasuki masa transisi memerlukan bantuan dan bimbingan dalam pemenuhan tugas tugas perkembangan yang harus dikuasai. Oleh karena itu, pendidikan tidak hanya mampu mengantarkan siswa pada standar kemampuan profesional dan akademis tetapi juga mampu membuat perkembangan diri sebagai remaja yang sehat dan produktif.

\section{KESIMPULAN}

1. Perilaku remaja di SMP Yayasan Pendidikan Shafiyyatul Amaliyyah Medan Tahun 2013 
sebagian besar memiliki perilaku baik sebanyak 88 orang $(50,9 \%)$.

2. Pengetahuan remaja di SMP Yayasan Pendidikan Shafiyyatul Amaliyyah Medan Tahun 2013 sebagian besar berpengetahuan baik sebanyak 136 orang $(78,6 \%)$.

3. Sikap remaja di SMP Yayasan Pendidikan Shafiyyatul Amaliyyah Medan Tahun 2013 sebagian besar memiliki sikap positif sebanyak 116 orang $(67,1 \%)$.

4. Tindakan remaja

5. di di SMP Yayasan Pendidikan Shafiyyatul Amaliyyah Medan Tahun 2013 sebagian besar memiliki tindakan baik sebanyak 157 orang $(90,8 \%)$.

\section{SARAN}

1. Agar tenaga kesehatan sebagai pelaksana pelayanan kesehatan reproduksi remaja lebih aktif mengadakan penyuluhan tentang kesehatan reproduksi bagi remaja dan orang tua.

2. Agar remaja lebih banyak menggali informasi baik melalui media cetak maupun media elektronik sehingga lebih memahami dampak negatif perilaku remaja terhadap perubahan fisiologis.

\section{DAFTAR PUSTAKA}

Agustiani, H. 2006. Psikologi perkembangan. Rafika aditama: Bandung

Ali, M. 2004. Psikologi remaja. Bumi aksara: Jakarta

Azwar, R. 2007. Sikap manusia teori dan pengukurannya. Yogyakarta : Pustaka Pelajar

Dariyo, A. 2004. Psikologi perkembangan remaja. Ghalia Indonesia: Bogor

Depkes. RI. (2010). Visi misi Indonesia sehat. Diambil 22 November 2012, dari http://www.depkes.go.id

Dewi, P. 2010. Perilaku remaja dalam menghadapi pubertas. Diambil 22 November 2012. http://www.repository.unand.ac.id
Fatwiany. 2010. Perubahan fisik remaja pada masa pubertas si SLTP Kemala Bhayangkari 1 Medan. Medan : Universitas Sumatera Utara

Gunarsa, S. 2000. Psikologi praktis : anak, remaja dan keluarga. Gunung mulia : Jakarta ., 2003. Psikologi remaja.Gunung mulia: Jakarta

Hidayat, AA. 2011. Metode penelitian kebidanan dan teknik analisa data. Jakarta : Salemba Medika

Hurlock, E. 1980. Psikologi perkembangan. Erlangga: Jakarta

Jahja, Y. 2011. Psikologi perkembangan. Prenada media: Jakarta

Mahmud, DM.2002. Psikologi suatu pengantar. BEFE.Yogyakarta

Maramis, W. 2006. Ilmu perilaku dalam pelayanan kesehatan. Airlangga: Surabaya

Notoatmojo, S. 2002. Pengantar Pendidikan Kesehatan dan Ilmu Perilaku Kesehatan. Penerbit Andi off seat. Yogyakarta

Pinem, S. 2009. Kesehatan reproduksi dan kontrasepsi. Trans info media: Jakarta

Purwanto, H. 1998. Pengantar Perilaku Manusia untuk keperawatan. EGC. Jakarta

Sanjaya, W. 2011. Kurikulum dan Pembelajaran. Kencana: Jakarta

Santrock, J. 2003. Adolescence perkembangan remaja. Erlangga: Jakarta

Santrock, JW. 1996. Adolescence Perkembangan Remaja. Erlangga. Jakarta

Soetjiningsih. 2004. Tumbuh kembang remaja dan permasalahannya. Sagung seto: Jakarta

Somantri, A. 2011. Aplikasi statistika dalam penelitian. Bandung : Pustaka Setia

Sujanto, A. 1986. Psikologi perkembangan. Aksara baru: Jakarta

Suyanto dan Salamah, U. 2009. Riset kebidanan metodologi dan aplikasi. Yogyakarta : Mitra cendikia pres

Yulianto, H. 2012. Program bimbingan pribadi-sosial untuk mengembangkan konsep diri siswa (studi deskriptif terhadap siswa kelas X SMA Negeri 24 Bandung Tahun Ajaran 2011-2012. Diambil 24 November 2012. http://www.repository.upi.edu

Widayatun, T. 1999. Ilmu perilaku. Sagung seto: Jakarta 